\title{
Effect of COVID-19 on platelet count and its indices
}

\author{
Ertuğrul Güçlü1 \\ (D) Havva Kocayiğit ${ }^{2}$ \\ (iD) Hüseyin Doğuş Okan ${ }^{1}$ \\ (iD) Unal Erkorkmaz ${ }^{3}$ \\ (D) Yusuf Yürümez ${ }^{4}$ \\ (iD) Selcuk Yaylaci ${ }^{5}$ \\ (iD) Mehmet Koroglu 6 \\ Cem Uzun ${ }^{1}$ \\ (iD) Oğuz Karabay'
}

\begin{abstract}
1. Sakarya University Faculty of Medicine, Department of Infectious Diseases and Clinical Microbiology, Sakarya, Turkey.
2. Sakarya University Training and Research Hospital, Division of Anesthesiology, Sakarya, Turkey. 3. Sakarya University Faculty of Medicine, Department of Biostatistics, Sakarya, Turkey.

4. Sakarya University Faculty of Medicine, Department of Emergency Medicine, Sakarya, Turkey. 5. Sakarya University Faculty of Medicine, Department of Internal Medicine, Sakarya, Turkey. 6. Sakarya University Faculty of Medicine, Department of Medical Microbiology, Sakarya, Turkey.
\end{abstract}

http://dx.doi.org/10.1590/1806-9282.66.8.1122

\section{SUMMARY}

BACKGROUND: Easily accessible, inexpensive, and widely used laboratory tests that demonstrate the severity of COVID-19 are important. Therefore, in this study, we aimed to investigate the relationship between mortality in COVID-19 and platelet count, Mean Platelet Volume (MPV), and platelet distribution width.

METHODS: In total, 215 COVID-19 patients were included in this study. The patients were divided into two groups. Patients with room air oxygen saturation $<90 \%$ were considered as severe COVID-19, and patients with $\geq 90 \%$ were considered moderate COVID-19. Patient medical records and the electronic patient data monitoring system were examined retrospectively. Analyses were performed using the SPSS statistical software. A p-value $<0.05$ was considered significant.

RESULTS: The patients' mean age was 64,32 $\pm 16,07$ years. According to oxygen saturation, 81 patients had moderate and 134 had severe COVID-19. Our findings revealed that oxygen saturation at admission and the MPV difference between the first and third days of hospitalization were significant parameters in COVID-19 patients for predicting mortality. While mortality was 8.4 times higher in patients who had oxygen saturation under $90 \%$ at hospital admission, 1 unit increase in MPV increased mortality 1.76 times.

CONCLUSION: In addition to the lung capacity of patients, the mean platelet volume may be used as an auxiliary test in predicting the mortality in COVID-19 patients.

KEYWORDS: Coronavirus Infections. Blood Platelets. Mean platelet volume. Mortality.

\section{INTRODUCTION}

The World Health Organization (WHO) ${ }^{1}$ declared a pandemic on March $11^{\text {th }}, 2020$, after the identification of > 118,000 novel 2019 coronavirus disease (COVID19) cases in 114 countries. As of 7 May 2020, a total of
$3,825,028$ cases had been identified in 187 countries, and unfortunately, 267,996 patients had died².

The clinical spectrum of COVID-19 appears to be wide, encompassing asymptomatic infection, mild

DATE OF SUBMISSION: 01-Jun-2020

DATE OF ACCEPTANCE: 02-Jun-2020

CORRESPONDING AUTHOR:Hüseyin Doğuş Okan

Adnan Menderes Caddesi Sağlık Sokak No: 195 Adapazarı - Sakarya -Turkey - 54000

E-mail: okanhd@hotmail.com 
upper respiratory tract illness, severe viral pneumonia with respiratory failure, and even death. In particular, older age, d-dimer levels greater than $1 \mu \mathrm{g} / \mathrm{mL}$, higher SOFA score on admission, and comorbidities such as cardiovascular disease, diabetes, chronic respiratory disease, and oncological diseases were associated with worse prognosis and in-hospital death ${ }^{3,4}$. Treatment strategies including drugs, vaccines, or targeted therapy approaches have been limited until now ${ }^{5}$. Easily accessible, inexpensive, and widely used laboratory tests that show the severity of COVID-19 are important. Mean platelet volume (MPV) and platelet distribution width (PDW) are widely and routinely used in clinical practice worldwide. Higher MPV and increased PDW have been found in sepsis, and PDW was found to be a poor prognostic factor in severe sepsis ${ }^{6}$. However, the role of these parameters in COVID-19 has not been investigated. In this study, we aimed to investigate the relationship between mortality in COVID-19 and platelet count, MPV, and PDW.

\section{METHODS}

\section{Study setting}

This is a retrospective cohort study that was conducted between April 01, 2020, and April 15, 2020, in a tertiary training and research hospital. The hospital where the study was conducted was designated as the coronavirus pandemic hospital in the province by the Ministry of Health. The hospital has a total of 400 patient beds, 85 of which are intensive-care beds. Patient medical records and the electronic patient data monitoring system were examined retrospectively. The study protocol was approved by the institutional review board of Sakarya University (IRB No:71522473/050.01.04/105).

\section{Study Group}

Patients diagnosed with COVID-19 were included. Complete blood count, C-reactive protein (CRP), and biochemistry tests are routinely performed on patients who attend the emergency department with complaints compatible with COVID-19 such as cough, fever, and shortness of breath. Also, Lung Computed Tomography (CT) is performed on patients who have shortness of breath, after their examination by the responsible doctor. At the same time, oro-nasopharyngeal swab (ONS) samples are taken from the patients for molecular analysis to reach a definitive diagnosis. Patients with advanced bilateral pneumonia, and/or tachypnea (respiratory rate $>26 /$ minute), and/or arterial oxygen saturation $<90 \%$ in room air are followed up in the intensive-care unit, while patients with moderate clinical symptoms are followed up in the hospital wards. A second swab sample was taken from hospitalized patients with a negative first sample. When one of the two samples taken was positive, the patient was diagnosed with COVID-19, and if both were negative, COVID-19 was excluded.

\section{Study design}

The patients were divided into two groups according to the lowest oxygen saturation during their first two days after hospital admission. Patients with oxygen saturation $<90 \%$ in room air were considered severe COVID-19, and patients with $\geq 90 \%$ were considered moderate COVID-19. Complete blood count and CRP values were obtained from patients on the day of hospital admission and on the third day of hospital follow-up. Patients who were discharged within 28 days after diagnosis of COVID-19 and who continued to undergo follow-up in the hospital on the $28^{\text {th }}$ day of patient monitoring were accepted as survivors. Patients who died within the 28 days of patient monitoring were recorded as non-survivors. Thrombocytopenia was defined as grade 1: absolute platelet count (APC) 150,000 - 100,000/ $\mathrm{mm}^{3}$; grade 2: 99,000 $-50,000 / \mathrm{mm}^{3}$; grade $3:<49,000 / \mathrm{mm}^{3}$. Lymphopenia was defined as grade 1: absolute lymphocytes count (ALC) 1500- 1000/ul; grade 2: ALC 999-750/ul; grade 3: ALC $<750 /$ ul.

\section{Statistical Analysis}

Descriptive analyses were performed to provide information on the general characteristics of the study population. The Kolmogorov-Smirnov test was used to evaluate whether the distribution of numerical variables was normal. Accordingly, two independent sample t-tests and one way ANOVA were used to compare the age between/among groups. The Mann Whitney U test and Kruskal Wallis H test were used to compare the non-normally distributed numeric variables between/among groups. The numeric variables were presented as the mean and standard deviations. Categorical variables were compared by the Chi-Square test. Categorical variables were presented as a count and percentage. A multiple logistic regression model was implemented to determine the risk factors independently associated with exit status and hospitalization time. A p-value $<0.05$ was considered significant. 
Analyses were performed using SPSS statistical software (IBM SPSS Statistics, Version 23.0. Armonk, NY: IBM Corp.)

\section{RESULTS}

In total, 215 COVID-19 patients were included in this study. The study population consisted of 95 females and 120 males, and their mean age was 64,32 $\pm 16,07$ years. According to oxygen saturation, 81 patients had moderate and 134 had severe COVID-19. Since nine of the patients were discharged $\leq 3$ days, they did not have a third-day analysis. Thrombocytopenia was observed in $54(25.1 \%)$ patients on the hospital admission day and in $52(24.1 \%)$ patients on the third follow-up day. On admission day, 43 patients had grade 1, 9 patients had grade 2, and two patients had grade 3 APC. On the third follow-up day, 40 patients had grade 1, 8 patients had grade 2 , and four patients had grade 3 APC. On admission day, severe COVID-19 patients had significantly higher white blood count (WBC), neutrophil, and CRP values than moderate
COVID-19 patients $(\mathrm{p}<0.05)$. On the third follow-up day, WBC, neutrophil, platelet, MPV, and CMV values were significantly higher in severe patients than moderate COVID-19 patients $(p<0.05)$. On admission day, 62 patients had grade 1, 34 patients had grade 2, and 44 patients had grade 3 ALC. On the third follow-up day, 52, 44, and 57 patients had grade 1, 2, and 3 ALC, respectively. The mean lymphocyte value was lower in severe COVID-19 cases compared to moderate COVID19 cases both on the day of hospital admission and on the third follow-up day $(\mathrm{p}<0.05)$. The difference among WBC, neutrophil, platelet, and CRP between two days in severe and moderate COVID-19 patients was significant $(p<0.05)$ (Table 1$)$.

Among the 215 COVID-19 patients, 56 (26.04\%) of them died within the 28-day follow-up. The age of the deceased patients was greater that that of the survivors. Thrombocytopenia was observed in 22 (39.3\%) of the non-survivors and in 31 (19.5\%) of the survivors ( $p=0.003$ ). WBC, neutrophil, CRP, and PDW in non-survivors were significantly higher than in survivors in both admission day and the third day of follow-up

TABLE 1. COMPARISON RESULTS OF THE HEMATOLOGICAL CHARACTERISTICS AND OTHER FEATURES BETWEEN SEVERE AND MODERATE COVID-19 PATIENTS.

\begin{tabular}{|c|c|c|c|c|c|}
\hline & \multicolumn{2}{|c|}{$\begin{array}{l}\text { Moderate COVID-19 } \\
(\geq 90 \mathrm{SaO} 2)\end{array}$} & \multicolumn{2}{|c|}{$\begin{array}{l}\text { Severe COVID-19 } \\
(<90 \mathrm{SaO} 2)\end{array}$} & \multirow[t]{2}{*}{$\mathrm{p}$} \\
\hline & $\mathrm{n}$ & Mean $\pm S D$ & $\mathrm{n}$ & Mean $\pm S D$ & \\
\hline Gender (Male) & 81 & $44(54.3)$ & 134 & $76(56.7)$ & 0.732 \\
\hline Age (years) & 81 & $56.52 \pm 15.95$ & 134 & $69.04 \pm 14.26$ & $<0.001$ \\
\hline White blood count (K/uL) & 81 & $6485.11 \pm 2016.83$ & 134 & $8960.72 \pm 5016.91$ & $<0.001$ \\
\hline Neutrophil (K/uL) & 81 & $4283.67 \pm 1846.83$ & 130 & $7792.15 \pm 7948.32$ & $<0.001$ \\
\hline Lymphocyte (K/uL) & 81 & $1573.53 \pm 523.33$ & 134 & $1389.35 \pm 1607.33$ & $<0.001$ \\
\hline Platelet $(\mathrm{K} / \mathrm{uL})$ & 81 & $187.4 \pm 59.82$ & 134 & $208.63 \pm 135.72$ & 0.573 \\
\hline Mean Platelet Volume (f/l) & 80 & $9.18 \pm 1.24$ & 132 & $9.61 \pm 1.76$ & 0.129 \\
\hline Platelet Distribution Width (\%) & 80 & $17.37 \pm 2.32$ & 132 & $17.72 \pm 2.52$ & 0.142 \\
\hline C-reactive protein $(\mathrm{mg} / \mathrm{L})$ & 81 & $34.69 \pm 43.05$ & 133 & $107.53 \pm 84.33$ & $<0.001$ \\
\hline White Blood Count 2 (K/uL) & 70 & $5714.4 \pm 2191.37$ & 129 & $9855.51 \pm 8228.18$ & $<0.001$ \\
\hline Neutrophil $2(\mathrm{~K} / \mathrm{uL})$ & 69 & $3795.51 \pm 1959.37$ & 127 & $8254.4 \pm 7233.19$ & $<0.001$ \\
\hline Lymphocyte 2 (K/uL) & 70 & $1501.57 \pm 892.05$ & 128 & $922.66 \pm 486$ & $<0.001$ \\
\hline Platelet $2(\mathrm{~K} / \mathrm{uL})$ & 70 & $172.93 \pm 67.58$ & 128 & $217.82 \pm 92.18$ & $<0.001$ \\
\hline Mean Platelet Volume $2(\mathrm{f} / \mathrm{I})$ & 69 & $9.38 \pm 1.42$ & 123 & $9.85 \pm 1.79$ & 0.043 \\
\hline Platelet Distribution Width $2(\%)$ & 70 & $17.96 \pm 1.43$ & 124 & $18.13 \pm 1.66$ & 0.144 \\
\hline C-reactive protein 2 (mg/L) & 64 & $36.92 \pm 41.73$ & 124 & $119.57 \pm 82.52$ & $<0.001$ \\
\hline White Blood count difference $(\mathrm{K} / \mathrm{uL})$ & 70 & $-757.19 \pm 2359.37$ & 129 & $1004.3 \pm 8033.14$ & 0.003 \\
\hline Neutrophil difference (K/uL) & 69 & $-511.11 \pm 2048.64$ & 123 & $585.45 \pm 9756.85$ & 0.006 \\
\hline Lymphocyte difference (K/uL) & 70 & $-29.19 \pm 851.87$ & 128 & $-473.22 \pm 1578.33$ & 0.341 \\
\hline Platelet difference $(\mathrm{K} / \mathrm{uL})$ & 70 & $-10.57 \pm 52.39$ & 128 & $10.24 \pm 126.49$ & 0.001 \\
\hline Mean Platelet Volume difference (f/I) & 68 & $0.08 \pm 0.89$ & 122 & $0.37 \pm 1.59$ & 0.301 \\
\hline Platelet Distribution Width difference (\%) & 69 & $0.61 \pm 2.34$ & 123 & $0.55 \pm 2.45$ & 0.913 \\
\hline C-Reactive Protein difference (mg/L) & 64 & $0.85 \pm 24.14$ & 124 & $14.4 \pm 94.77$ & 0.040 \\
\hline Hospitalization day & 81 & $6.01 \pm 3.49$ & 134 & $14.75 \pm 8.6$ & $<0.001$ \\
\hline
\end{tabular}


TABLE 2. DIFFERENCE IN AGE, GENDER AND HEMATOLOGICAL CHARACTERISTICS BETWEEN SURVIVORS AND NON-SURVIVORS OF PATIENTS WITH COVID-19

\begin{tabular}{|c|c|c|c|c|c|}
\hline & \multicolumn{2}{|c|}{ Survivors } & \multicolumn{2}{|c|}{ Non-survivors } & \multirow[t]{2}{*}{$\mathrm{P}$} \\
\hline & $n$ & Mean \pm SD & $n$ & Mean \pm SD & \\
\hline Gender (Male) & 159 & $87(54.7)$ & 56 & 33 (58.9) & 0.697 \\
\hline Age (years) & 159 & $61.15 \pm 16$ & 56 & $73.34 \pm 12.58$ & $<0.001$ \\
\hline White blood count (K/uL) & 159 & $7569.78 \pm 3940.36$ & 56 & $9329.21 \pm 5046.97$ & 0.011 \\
\hline Neutrophil $(K / u L)$ & 157 & $6037.69 \pm 7077.53$ & 54 & $7630.35 \pm 4598.34$ & $<0.001$ \\
\hline Lymphocyte (K/uL) & 159 & $1563.2 \pm 1432.63$ & 56 & $1162.14 \pm 812.23$ & 0.004 \\
\hline Platelet $(\mathrm{K} / \mathrm{uL})$ & 159 & $207.69 \pm 123.06$ & 56 & $180.59 \pm 78.14$ & 0.094 \\
\hline Mean Platelet Volume (f/I) & 158 & $9.34 \pm 1.37$ & 54 & $9.77 \pm 2.11$ & 0.189 \\
\hline Platelet Distribution Width (\%) & 158 & $17.44 \pm 2.35$ & 54 & $18.02 \pm 2.69$ & 0.040 \\
\hline C-reactive protein $(\mathrm{mg} / \mathrm{L})$ & 159 & $67.87 \pm 70.21$ & 55 & $114.92 \pm 94.73$ & $<0.001$ \\
\hline White Blood Count $2(\mathrm{~K} / \mathrm{uL})$ & 148 & $7499.39 \pm 4804.14$ & 51 & $11009.02 \pm 10877.1$ & 0.001 \\
\hline Neutrophil $2(\mathrm{~K} / \mathrm{uL})$ & 146 & $5777.12 \pm 4695.94$ & 50 & $9334.8 \pm 9117.4$ & $<0.001$ \\
\hline Lymphocyte 2 (K/uL) & 147 & $1259.44 \pm 734.31$ & 51 & $746.55 \pm 477.17$ & $<0.001$ \\
\hline Platelet $2(\mathrm{~K} / \mathrm{uL})$ & 147 & $206.52 \pm 84.72$ & 51 & $188.78 \pm 92.26$ & 0.348 \\
\hline Mean Platelet Volume $2(\mathrm{f} / \mathrm{I})$ & 146 & $9.45 \pm 1.47$ & 46 & $10.41 \pm 2.07$ & 0.005 \\
\hline Platelet Distribution Width 2 (\%) & 147 & $17.89 \pm 1.55$ & 47 & $18.63 \pm 1.56$ & 0.006 \\
\hline C-reactive protein $2(\mathrm{mg} / \mathrm{L})$ & 137 & $78.3 \pm 79.75$ & 51 & $126.71 \pm 75.31$ & $<0.001$ \\
\hline White Blood count difference $(\mathrm{K} / \mathrm{uL})$ & 148 & $-144.61 \pm 3963.6$ & 51 & $1920.67 \pm 11237.2$ & 0.182 \\
\hline Neutrophil difference $(\mathrm{K} / \mathrm{uL})$ & 144 & $-435.75 \pm 7132.57$ & 48 & $2072.73 \pm 9731.54$ & 0.175 \\
\hline Lymphocyte difference (K/uL) & 147 & $-285.1 \pm 1545.15$ & 51 & $-406 \pm 724.5$ & 0.048 \\
\hline Platelet difference $(\mathrm{K} / \mathrm{uL})$ & 147 & $-0.05 \pm 117.13$ & 51 & $11.33 \pm 68.25$ & 0.561 \\
\hline Mean Platelet Volume difference $(f / I)$ & 145 & $0.05 \pm 1.08$ & 45 & $0.96 \pm 1.94$ & 0.005 \\
\hline Platelet Distribution Width difference (\%) & 146 & $0.46 \pm 2.35$ & 46 & $0.93 \pm 2.57$ & 0.389 \\
\hline C-Reactive Protein difference $(\mathrm{mg} / \mathrm{L})$ & 137 & $8.15 \pm 68.63$ & 51 & $14.19 \pm 100.72$ & 0.091 \\
\hline Hospitalization day & 159 & $11.92 \pm 8.63$ & 56 & $10.13 \pm 7.08$ & 0.456 \\
\hline
\end{tabular}

*: Shown as count and percentage

$(\mathrm{p}=0.001)$. On the other hand, MPV in non-survivors was significantly lower than in survivors only in the third follow-up day $(\mathrm{P}<0.005)$. The demographic and laboratory findings of survivors and non-survivors are seen in table 2.

According to the multiple logistic regression model for mortality, in case of an increase of 1 unit MPV difference (MPV differences between $1^{\text {st }}$ and $3^{\text {rd }}$ day), the probability of death increases 1.762 times. In addition, the probability of death of patients with oxygen saturation $<90 \%$ is 8.405 times higher than that of patients with oxygen saturation $\geq 90 \%$ (table 3 ).

TABLE 3. MULTIPLE LOGISTIC REGRESSION MODEL FOR MORTALITY.

\begin{tabular}{l|l|l|l|l|l} 
& $\beta$ & SE of $\beta$ & $p$ & OR & $\begin{array}{l}95 \% \mathrm{Cl} \text { for } \\
\text { OR }\end{array}$ \\
\hline Age & -0.042 & 0.007 & $<0.001$ & 0.959 & $0.945-0.973$ \\
\hline $\begin{array}{l}\text { Oxygen } \\
\text { saturation }\end{array}$ & 2.129 & 0.528 & $<0.001$ & 8.405 & $2.987-23.646$ \\
\hline MPV diff & 0.566 & 0.166 & 0.001 & 1.762 & $1.272-2.440$ \\
\hline
\end{tabular}

$\bar{\beta}$ : regression coefficient, SE: standard error, OR: odds ratio, Cl: confidence interval, MPV: Mean platelet volume

\section{DISCUSSION}

Our findings revealed that oxygen saturation at admission and MPV difference between the first and third days of hospitalization were significant parameters in COVID-19 patients for predicting mortality. While, mortality was 8.4 times higher in patients who had oxygen saturation under $90 \%$ at hospital admission, 1 unit increase in MPV between the first and third days of hospitalization increases mortality 1.76 times. In addition to the lung capacity of the patient, MPV may be used as an auxiliary test in predicting the mortality in COVID-19 patients.

Primary inflammation triggered by rapid viral replication and release of potent proinflammatory cytokines occurs in the early stages of COVID-19 infection ${ }^{7}$. In addition to pulmonary infiltrate and diffuse alveolar damage, widespread endothelial inflammation due to viral infection of the endothelial cell can strengthen the further secretion of various inflammatory cytokines ${ }^{8}$. Neutrophils and leukocytes might reinforce the cytokine storm other 
than lymphocytes in COVID-19 because prominent lymphopenia has been developed in most COVID-19 patients, especially in severe ones ${ }^{9}$. In a meta-analysis, researchers found that severe illness was associated with lower lymphocyte and higher leukocyte counts $^{10}$. In our study, while the leukocyte and neutrophil values of severe cases on the day of admission to hospital were higher than in mild cases, the lymphocyte values were low, too $(p<0.05)$. Moreover, on the third day of hospitalization, leukocyte and neutrophil levels were increased even more in severe cases and decreased in mild cases $(\mathrm{p}<0.05)$. However, on the third day, although the lymphocyte values in severe cases decreased much more than in mild cases, the difference was not significant.

Zhao et al. ${ }^{11}$ reported that a lymphocyte count of less than $1.5 \times 10^{9} / \mathrm{L}$ may be useful in predicting the severity of clinical outcomes. They found that there was a three-fold increased risk of severe COVID-19 with the presence of lymphopenia. Our study revealed that leukocyte and neutrophil values in non-surviving patients were higher than in survivors both on the day of admission and on the third day of the follow-up, but the difference in the increase between the first and third days was not significant. On the other hand, the decrease in lymphocyte values of the patients who died was significant. Therefore, the power of the decrease in lymphocyte value in showing mortality was higher than that of the elevation in leukocyte and neutrophils. So, clinicians should closely monitor patients with lymphopenia.

Some studies have found a relationship between thrombocytopenia and the severity of the COVID19 and related mortality. It has been reported that mortality increases as platelet count decreases ${ }^{12,13}$. Interestingly in our study, although thrombocytopenia was more likely to occur in non-survivors than in survivors, we did not find any correlation between platelet level and disease severity or mortality.

TABLE 4. MULTIPLE LINEAR REGRESSION MODEL FOR HOSPITALIZATION DAY.

\begin{tabular}{l|l|l|l|l} 
& $\beta$ & SE of $\beta$ & $p$ & $95 \%$ Cl for $\beta$ \\
\hline Age & 0.053 & 0.035 & 0.130 & $-0.016-0.121$ \\
\hline Oxygen saturation & 8.548 & 1.134 & $<0.001$ & $6.310-10.786$ \\
\hline MPV difference & -0.905 & 0.382 & 0.019 & $-1.658--0.152$ \\
\hline Constant & 3.508 & 2.173 & 0.108 & $-0.780-7.796$ \\
\hline
\end{tabular}

$\beta$ : regression coefficient, SE: standard error, Cl: confidence interval, MPV: Mean platelet volume
Non-survivors had lower platelet counts than survivors on both admission day and third follow-up day, but this difference was not statistically significant. Similar to our study, other studies reported that platelet values were found to be normal in many patients at the time of hospital admission ${ }^{14}$. These differences between studies may be related to the time of the tests. Also, hydroxychloroquine, azithromycin, and enoxaparin treatment have been started in most countries when COVID-19 is suspected. These drugs can cause thrombocytopenia ${ }^{15,16}$. Another reason for the difference between studies may be that thrombocytopenia caused by drugs and thrombocytopenia caused by the disease present an intricate structure.

On the other hand, platelet indices, MPV, and PDW, were found to be higher in non-survivors on both admission day and third follow-up days. To our knowledge, this study is the first one specialized in the association between platelet indices and in-hospital mortality in patients with COVID-19. According to our results, every 1 unit increase in MPV increased mortality by 1.76 times. The mechanism of change in platelet indices in COVID-19 patients is probably multifactorial. Three hypotheses related to platelet count and structure are proposed in COVID-19. Firstly, as with other coronavıruses, thrombocytopenia is possibly due to infection of the bone marrow. Secondly, platelet destruction by the immune system. Thirdly, platelet consumption due to aggregation in the lungs ${ }^{17}$. Generally, platelet production increases as platelet count decreases. An increased number of young platelets is also functionally more active than older platelets. These changes may explain the increase in platelet indices, MPV, and PDW.

\section{LIMITATIONS}

In this rapidly emerging new non-characteristic infection of the modern medical age, it is necessary to identify biomarkers that can predict the severity and prognosis of the disease. MPV and PDW can be a simple, economical, fast, and widely available laboratory parameter that can distinguish directly between COVID patients with and without a severe presentation of the disease. Moreover, MPV can also be used to predict the mortality in COVID-19. In order to show the strength of these parameters more clearly, studies with a large number of patients are needed. 


\section{RESUMO}

OBJETIVO: Testes laboratoriais de fácil acesso, baixo custo e amplamente utilizados capazes de demonstrar a gravidade da COVID-19 são importantes. Portanto, neste estudo, o nosso objetivo foi investigar a relação entre a mortalidade na COVID-19 e a contagem de plaquetas, volume plaquetário médio (VMP) e largura de distribuição de plaquetas.

MÉTODOS: No total, 215 pacientes com COVID-19 foram incluídos no estudo. Os pacientes foram divididos em dois grupos. Pacientes com saturação de oxigênio < $90 \%$ em ar ambiente foram considerados casos graves de COVID-19 e pacientes com valores $\geq 90 \%$ foram considerados casos moderados. Os registros médicos dos pacientes e o sistema eletrônico de monitoramento de dados de pacientes foram analisados retrospectivamente. As análises foram realizadas utilizando o software estatístico SPSS. Um valor de $p<0,05$ foi considerado significativo.

RESULTADOS: A média de idade dos pacientes foi de 64,32 \pm 16,07 anos. Com base na saturação de oxigênio, 81 pacientes eram casos moderados e 134 tinham COVID-19 grave. Nosso estudo revelou que a saturação de oxigênio no momento da internação e a diferença nos valores de VPM entre o primeiro e terceiro dia de internação foram parâmetros significativos para predizer mortalidade de pacientes com COVID-19. A mortalidade foi 8,4 vezes maior nos pacientes com saturação abaixo de 90\% no momento da internação, mas um aumento de apenas 1 unidade no valor de VPM aumentou a mortalidade 1,76 vezes.

CONCLUSÃO: Além da capacidade pulmonar dos pacientes, o volume plaquetário médio pode ser utilizado como um teste auxiliar para prever a mortalidade de pacientes com COVID-19.

PALAVRAS-CHAVE: Infecções por Coronavirus. Plaquetas. Volume Plaquetário Médio. Mortalidade.

\section{REFERENCES}

1. World Health Organization. WHO declares COVID-19 a pandemic. 2020 [cited 2020 March 13]. Available from: https://www.who.int/dg/speeches/ detail/whodirector-general-s-opening-remarks-at-the-media-briefing-onCOVID-19---11- march-2020

2. Johns Hopkins University and Medicine. Coronavirus Resource Center. COVID-19 Dashboard by the Center for Systems Science and Engineering (CSSE) at Johns Hopkins University (JHU). [cited 2020 May 7]. Available from: https://coronavirus.jhu.edu/map.htm

3. Zhou F, Yu T, Du R, Fan G, Liu Y, Liu Z, et al. Clinical course and risk factors for mortality of adult inpatients with COVID-19 in Wuhan, China: a retrospective cohort study. Lancet. 2020;395(10229):1054-62.

4. Cascella M, Rajnik M, Cuomo A, Dulebohn SC, Di Napoli R. Features, evaluation and treatment coronavirus (COVID-19). Treasure Island: StatPearls Publishing; 2020. [cited 2020 May 12]. Available from: https://www.ncbi. nlm.nih.gov/books/NBK554776/

5. Pascarella G, Strumia A, Piliego C, Bruno F, Del Buono R, Costa F, et al. COVID-19 diagnosis and management: a comprehensive review. J Intern Med. 2020;10.1111/joim.13091.

6. Guclu E, Durmaz Y, Karabay O. Effect of severe sepsis on platelet count and their indices. Afr Health Sci. 2013;13(2):333-8.

7. Fu Y, Cheng $Y, W u$ Y. Understanding SARS-CoV-2-mediated inflammatory responses: from mechanisms to potential therapeutic tools. Virol Sin. 2020;1-6. doi: 10.1007/s12250-020-00207-4

8. Varga Z, Flammer AJ, Steiger P, Haberecker M, Andermatt R, Zinkernagel AS, et al. Endothelial cell infection and endotheliitis in COVID-19. Lancet. 2020;395(10234):1417-8.
9. Tufan A, Avanoğlu Güler A, Matucci-Cerinic M. COVID-19, immune system response, hyperinflammation and repurposing antirheumatic drugs. Turk J Med Sci. 2020;50(SI-1):620-32.

10. Huang G, Kovalic AJ, Graber C). Prognostic value of leukocytosis and lymphopenia for coronavirus disease severity. Emerg Infect Dis. 2020;26(8). doi: 10.3201/eid2608.201160.

11. Zhao Q, Meng M, Kumar R, Wu Y, Huang |, Deng Y, et al. Lymphopenia is associated with severe coronavirus disease 2019 (COVID-19) infections: a systemic review and meta-analysis. Int J Infect Dis. 2020;96:131-5.

12. Lippi G, Plebani M, Henry BM. Thrombocytopenia is associated with severe coronavirus disease 2019 (COVID-19) infections: a meta-analysis. Clin Chim Acta. 2020;506:145-8.

13. Yang $X$, Yang $Q$, Wang $Y$, Wu $Y, X u$ J, Yu Y, et al. Thrombocytopenia and its association with mortality in patients with COVID-19. J Thromb Haemost. 2020;18(6):1469-72.

14. Fan BE, Chong VCL, Chan SSW, Lim GH, Lim KGE, Tan GB, et al. Hematologic parameters in patients with COVID-19 infection. Am J Hematol. 2020;95(6):E131-4.

15. Butt MU, Jabri A, Elayi SC. Azithromycin-ınduced thrombocytopenia: a rare etiology of drug-induced immune thrombocytopenia. Case Rep Med. 2019;2019:6109831.

16. Demir D, Öcal F, Abanoz M, Dermenci H. A case of thrombocytopenia associated with the use of hydroxychloroquine following open heart surgery. Int | Surg Case Rep. 2014;5(12):1282-4.

17. Xu P, Zhou Q, Xu J. Mechanism of thrombocytopenia in COVID-19 patients. Ann Hematol. 2020;99(6):1205-8. 